\title{
The Morning Prayer in Greek Kindergartens as a Field of Exercising Multiculturalism
}

\author{
Konstantinos Tsioumis
}

Aristotle University of Thessaloniki

\author{
Argyris Kyridis \\ Aristotle University of Thessaloniki \\ akiridis@nured.auth.gr
}

\section{Zoe Konstantinidou}

Aristotle University of Thessaloniki

\section{Doi:10.5901/jesr.2013.v3n2p65}

\begin{abstract}
:
Religious education has been an issue of social and political debate in many countries but mostly in countries where people from different national, cultural and religious origins live. Religious identity is a core element of a person's identity that constitutes a crucial right of the person and its personal freedom. Every country and every state should protect the right of its citizens to exercise their religious duties. One of these duties is the prayer. However, some countries that experienced waves of migration during the last years do not have yet adjusted to taking the proper measures in order to overcome the transformation of the cultural composition of the their people. Greece is one of these countries. In Greek schools, every morning, the pupils and the teachers pray according to the ritual of the Greek Orthodox Church. This lead us to the research question of this paper: what happens with pupils whose religious faith is different and how do teachers face this problem? Our research hypothesis is that the way that teachers cope with the issue of the Morning Prayer is an issue of multicultural education, as well. For the purpose of our study we asked from 99 kindergarten teachers to inform us on (a) how they cope with the Morning Prayer and (b) how they treat the presence of children from culturally diverse backgrounds. Teachers' responses show that a remarkable percentage of the kindergarten teachers do not cope with this specific issue in a dogmatic way. They try to exercise a multicultural pedagogic in their classrooms.
\end{abstract}

Keywords: learning style; Morning Prayer; preschool education; multiculturalism; kindergarten teachers' practices;

\section{Introduction}

Social phenomena related to religious affiliation such us the headscarf movement in European countries of the faith schools movement are challenging the foundations of European modernity. The place of the religion in public education systems represents this reality (Zambeta, 2008: 297). Recent studies on the relationship between religion and education seem to adopt the view that the study of religion is a pre-condition for tolerance and social awareness of religious diversity, as a parameter of social responsibility. In several cases the religious education is seen as part of citizenship education in a brooder sauce. Religions are not a field of epistemic inquiry (Zambeta, 2008: 298). According to Durkheim (1995) religion is a rather subject for science than a science itself. Religions are formulations of doctrines that lie beyond reason. The discouragement of religion is not based on any system of dialectic argumentation. The coexistence of religion respects the survival of traditions in these societies. Theoretically the educational systems constitute an attempt towards secularization and the displacement of church in the control of education. The secularization process is whether 
neither universal nor radical in all European societies. In many European societies church has the right to establish confessional schools to give to the possibility to catechism. In Creech public schools religion is a compulsory subject, and has more of less to do with the dominant orthodox religion. In Denmark is taught the subject "Christian Studies". In countries like Germany, Belgium or Luxemburg there is the alternative of a "secular ethics". The place of religion in public schools confronts us with fundamental questions about the social role of education institutions in modern democracies (Zambeta, 2008: 300). A question is, does the dominant religious majority have the right to dogmatize through public education. These answers are critical for the conceptualization of the democracy religious freedom and social rights.

\section{Prayer in Schools}

The issues of the religious freedom and the religious identity are closely connected to the whole development of a person's identity. Families are responsible for decisions concerning the religious education of children both with the cultivation of the primary values which are dominant within every society. Nevertheless, at the same time the role of the school for the religious education remains crucial for the formulation of the cultural identity of children (Pantazis and Sakellariou, 2003; Derman - Sparks \& ABC Task Force, 2004).

The issue of school prayer leaves people deeply divided and confused. Any type of school prayer involves school officials in the approval and the development process of a daily school prayer and the decision when and where the students should pray. Prayer in schools is different. Despite complaints from conservative religious groups the prayer has been removed from the schools in the USA after the Supreme Court's decision of the early '60is. The students can pray private but it is not acceptable that the prayer is sponsored by the school and it is important that the students are not pressured to attend. Even schools do not sponsored school prayer does not mean that students cannot express their personal religious. Loconte has noted that school prayer advocates express the view that the schools have the responsibility to acknowledge the Deity, because the denial of God in civic live has important social consequences (Romanowski, 2002: 155-156))

An important problem is that the school prayer does not in fact recognize the deeply spiritual character of prayer as the time during which the people drew near to the presence of the God. It should also be noted that administrators, teachers and students view not the prayer time seriously. Experiences from the public schools saw that the students didn't respond seriously to the school prayer (Romanowski, 2002: 158).

Another problem with the prayer is in schools, where there are students whose faith differs from that $f$ the majority. The presence of the religious diversity should remind us that there are many different kinds of prayers and diverse ways of praying. The advocates of the school prayer often fail to respect the religious diversity of the minority citizens. Prayer is the central element of all religions and is defined in different ways in different religious traditions. For Christians God is identified as Abba by Jesus a lovely father. (Foster 1992).In Jewish traditions prayer is the expression of a man constant awareness of the divine (Cohn and Fish 1996). In Islam prayer is considered as a foundation of religion which saws submission as central to the spirit of worship.

Religion is a part of the social and the cultural identity of every person who lives in a community. Religion both with the ethnic and the cultural characteristics of a person or of a group of persons formulate their main identity or some parts of their identities. In every society there are the dominant identity/ies which are thought to be the right identity. And this is the beginning point of the formulation of racism. Speaking about children Cross (1985) argued that "there are two distinguishable effects of racism on ethnic minority children's identity. The first is personal identity which includes self-esteem, confidence and self-evaluation and the second is reference group orientation which develops racial identity, race esteem and racial ideology" (Siraj-Blatchford, 1996: 64). Kindergarten aims to help children to develop their personalities and their future academic performance. But it seems to be a contradiction in terms when social and educational practices in kindergartens become barriers for the development of the children with different identities than the dominant.

\section{Morning Prayer in Greek Schools}

Greece which has been an emigration country has shifted to transit country for a significant number of migrants on their way for richer countries of EU to a destination country with a $10 \%$ of its population composed of migrants. These changes led to the introduction of intercultural education to the Greek educational system and 
to the development of respective policies the last two decades. The Greek intercultural education policy has been developed with the financial assistance (aid) of European Union and partly of the Council of Europe which implemented programs aiming to increase the tolerance for diversity between the European peoples. The scope of the particular programs was to develop pedagogical methods, curriculum, minority schooling and educational research. The initiatives have been implemented in different ways (Gropas and Triantafyllidou, 2011; Luciac, 2006).

The implementation of these policies was not easy because the increase of the culturally diverse population made difficult for the educational community to meet the needs of the minority populations. A percentage of the Greek educators perceived of migrants as threat for the Greek identity. Although their educational practices have not been aggressive against the foreign pupils the stereotypical thinking and acting has often been visible.

Within this very context, a lot of protest arose concerning issues related with the national and religious identity. Mainly, the issue of the history teaching and the issue of the religious education became the core elements of the social and educational controversy. At the same time this controversy fed a political debate.

Particularly in Greece, religion had been always a key element in public life, especially in education. These are historians witch argue about the independence of region and Greek identity. Other scholars speak about the deference between Hellenism and Christianity. In Durkheim's opinion religious is an authoritative dynamic system of social ideals and beliefs that shape a common perception of a society's moral universe. The construction of national identity has to do with the determination of the self and with the process of determining and excluding the other. Greek education is an institution the aim of which has been the production of national identity (Zambeta, 2000). Orthodoxy is recognized by the Greek Constitution as the prevailing religion in the Greek State combined with the constitutions demand for the development of national and religious consciousness of Greek citizens as basic aim of education, according article 16.2 of the Constitution. The current cross-thematic curriculum for the Greek schools aims the acquisition of Christian faith and the Promotion of Orthodox spirituality as individual and collective experience. This curriculum aims of multicultural character of education by excluding students of different religious backgrounds (Efstathiou et al., 2008; Zambeta, 2000). No other religion is taught in the mainstream education with the exceptions of the Muslim minority of Western Thrace.

The morning -prayer in all Greek schools is a custom and an obligation for the Greek teachers and is held everyday in all schools of the country. Students can be excepted from the prayer after a request of their parents or guardians. This option satisfies the constitutional claim.

A current trued for Greek educational policy is to associate religion with cultural events following (Efstathiou et al., 2008). Coulby's (2008) position according which religious teaching can be more effective through cultural events than explicit teaching.

It can be said that the full exercise of social and cultural rights and the religious freedom of other religious groups such as Catholic Christians or Jehovah's Witnesses, is not enough provided. Religion is an in strict part of the Greek culture and the collective morning prayer is a part of this reality. Only a small part of the Greek society seems to support the view for a division between church and state.

As J. Gundara puts it the critical question is the complex ways in which religion ought to be refers within public institutions to bring about on inclusive value system rather than strengthen exclusivities. Given the different social structures the practice of individual and social rights is something that the educators school take into account in order to develop a more realistic and cultural responsive practice of the rights of their students (Gundara, 1990). Secularism is a legal system which provides the public level and to safeguard the sacred in the private level. Secular collectivity is not necessarily theistic atheistic or aquatic (Verma, 1986). It provides therefore a nest for the protection of the citizenship rights. According Gundara positive secularism goes beyond the religious toleration of other groups and refers to the belongingness of all groups in society.

In some states of the U.S. student prayer in the classroom was acceptable if it didn't disrupt the classroom activities and if it didn't be offensive to other students in the classroom. So, students could pray silent and no matter the class is not dedicated to pray (Mays and Ferrim, 2001) point that answers of the educated are that such a position is not allowed by the laws, but if a child does so, they give to him/she the time needed (Mayes and Ferrin, 2001). In the same study another teacher reported morning and no one challenged them. There were many teachers which promoted the Morning Prayer at school. During the Reagan, presidency a debate has been 
developed about the prayer at the schools. A part of senators or congressmen spoke about the opportunity to pray voluntary at schools and the opponents asked for the neutral position of the government in matters of religion (Mc Andrews, 2003).

\section{The research methodology}

The Morning Prayer is not seen as main trend in all elementary schools worldwide. To pray is not so usual in kindergarten. This has to do with the position on educational system takes is issues related with the development of the personal identity during early school hood.

Despite of this, the Morning Prayer is a tradition in Greek kindergarten and as such is it seen from the educators. Our research effort tried to investigate the manner in which the Greek teachers of the kindergarten act about the Morning Prayer, which is more or less sponsored by the mainstream educational system. The main aim of the research is to illustrate how kindergarten teachers cope with multiculturalism, responding to the compulsory Morning Prayer. It seems to be a contradiction in terms that the rising multiculturalism in Greek society and schools is opposed to traditional practices. Kindergarten teachers have to decide whether they are multicultural or traditional.

Ninety nine (99) kindergarten teachers where asked to response the following questions:

- How do you cope with the Morning Prayer?

- How do you treat the presence of the children of culturally diverse backgrounds?

Regarding the analysis of the written statements of the subjects we used the methodological tool of Quantitative and Qualitative Content Analysis, which, as Curley (1990) states, allows (a) the combination of quantitative and qualitative data, (b) traces and records the types of social interaction through discourse analysis, (c) records historic and cultural elements, (d) records and analyzes social ideologies and (e) investigates concepts as well as the ways in which the specific concepts are perceived by social subjects. In detail, the texts were analyzed following the principles of Quantitative Content Analysis, as they were stated by Holsti (1969), Berelson (1971), De Sola Pool (1959), Palmquist (1990), Weber (1990) and by French researchers (Moscovici, 1970; Mucchielli, 1988; Veron, 1981; Bardin, 1977; Grawitz, 1981) (classical thematic analysis). The "theme" was considered as the basic unit of analysis (Lasswell, Lerner \& Sola Pool, 1952; Lasswell \& Leites, 1965).

\section{Findings}

Table 1. Demographic characteristics of the sample

\begin{tabular}{|c|c|c|c|c|c|}
\hline Gender & \multicolumn{2}{|l|}{$\mathbf{N}$} & \multicolumn{3}{|l|}{$\%$} \\
\hline Male & \multicolumn{2}{|l|}{2} & \multicolumn{3}{|l|}{2} \\
\hline Female & \multicolumn{2}{|l|}{97} & \multicolumn{3}{|l|}{98} \\
\hline $\begin{array}{l}\text { Professional occupation in } \\
\text { kindergarten }\end{array}$ & $\mathbf{N}$ & $\%$ & $\begin{array}{l}\text { Years of work } \\
\text { experience }\end{array}$ & $\mathbf{N}$ & $\%$ \\
\hline Nursery Teacher & 15 & 14,7 & $1-5$ years & 13 & 13,1 \\
\hline Teacher & 66 & 66,7 & $6-10$ years & 28 & 28,3 \\
\hline \multirow[t]{2}{*}{ Specialized teacher } & 9 & 8,8 & $11-20$ years & 36 & 36,4 \\
\hline & & & More than 21 years & 22 & 22,2 \\
\hline $\begin{array}{l}\text { Teacher of a specific discipline } \\
\text { in Secondary education }\end{array}$ & 12 & 11,8 & Place of work & $\mathbf{N}$ & $\%$ \\
\hline \multirow{4}{*}{\multicolumn{3}{|c|}{ Type of educational degree }} & Urban area & 55 & 55,6 \\
\hline & & & Semi - urban area & 25 & 25,3 \\
\hline & & & Rural area & 8 & 8,1 \\
\hline & & & $\mathbf{N}$ & \multicolumn{2}{|l|}{$\%$} \\
\hline \multicolumn{3}{|l|}{ School of pedagogics } & 9 & \multicolumn{2}{|l|}{9,1} \\
\hline
\end{tabular}




\begin{tabular}{|l|l|l|}
\hline University degree & 60 & 60,6 \\
\hline 2nd class degree in pedagogics & 23 & 23,2 \\
\hline Postgraduate degree & 7 & 7,1 \\
\hline Ph.D. degree & 0 & 0 \\
\hline
\end{tabular}

Table 2. Kindergarten teacher's choices concerning the Morning Prayer

\begin{tabular}{|l|l|l|}
\hline Prayer & N & \% \\
\hline Christian prayer & 58 & 58,6 \\
\hline General prayer & 30 & 30,3 \\
\hline None & 4 & 4 \\
\hline More than one prayer according to the composition of the class & 7 & 7,1 \\
\hline Total & 99 & 100 \\
\hline
\end{tabular}

Table 3. Level of tolerance according to the practices adopted by the kindergarten teachers

\begin{tabular}{|l|l|l|}
\hline Level of tolerance & N & \% \\
\hline Not at all & 18 & 18,2 \\
\hline Partial & 63 & 63,6 \\
\hline Much & 18 & 18,2 \\
\hline Total & 99 & 100 \\
\hline
\end{tabular}

This study includes kindergarten teachers $(\mathrm{N}=99, \mathrm{~N}=2$ male, female $\mathrm{N}=97)$ from Greece. $55,6 \%$ of the participants work in urban areas, $25,3 \%$ in semi urban and $8,1 \%$ in regions of rural areas. The majority of teachers has eleven to twenty years $(36,4 \%)$ experience and six to ten years $(28,3 \%)$ and holds a permanent position $(82,8 \%)$. Regarding education, the majority $(60,6 \%)$ has four-year education and the $23,2 \%$ has further training. More than half of the participants report to say a Christian prayer in the classroom $(58,6 \%)$ while $30,3 \%$ say a general one. Only 7,1\% of all of the participants report to say prayers of many religions in the classroom, depending on the religion of children, while $4 \%$ report that they do not say any prayer. Finally, the majority of the sample seems to handle the issue of prayer with tolerance $(63,6 \%)$ (e.g. "There is no reason not to do the cross because we might have children who believe in another God", while the remaining $36,4 \%$ is equally distributed between extreme tolerant and extreme intolerant behaviors (e.g. "If a child does not want, he/she can just sit quietly and wait for others to finish", or "One year, children of my class came up with an idea of everyone whispering the name of the God that they believe in (for example Allah) instead of the word "God". The proposal was implemented").

Table 4. Thematic Analysis of the responses at the question (How do you treat the presence of the children of culturally diverse backgrounds?)

\begin{tabular}{|l|l|l|l|}
\hline Themes & & $\mathbf{\%}$ & Statements \\
\hline \multirow{4}{*}{$\begin{array}{l}\text { Theme } \\
\mathbf{1}\end{array}$} & Imposition of Christian Prayer & $\mathbf{1 5 , 2}$ & \\
\cline { 2 - 5 } & Yes & 6,8 & They have to do the cross like the Greek children. \\
\cline { 2 - 5 } & No & 9,4 & $\begin{array}{l}\text { A student who wants to pray to whatever he/she } \\
\text { believes in is completely free to do so. }\end{array}$ \\
\hline \multirow{3}{*}{$\begin{array}{l}\text { Theme } \\
\mathbf{2}\end{array}$} & Prayer as exceptional right & $\mathbf{2 2 , 7}$ & \\
\cline { 2 - 5 } & Yes & 13,6 & $\begin{array}{l}\text { They are allowed to pray in their own way, if they } \\
\text { want, at the same time with us or after us or not to } \\
\text { pray at all. }\end{array}$ \\
\hline
\end{tabular}




\begin{tabular}{|c|c|c|c|}
\hline & No & 9,7 & $\begin{array}{l}\text { All children, regardless of religion, have to slowly } \\
\text { follow the prayer that we make. }\end{array}$ \\
\hline \multirow{3}{*}{$\begin{array}{l}\text { Theme } \\
3\end{array}$} & $\begin{array}{l}\text { Selection of prayer according to } \\
\text { the class composition }\end{array}$ & 12,4 & \\
\hline & Yes & 10,0 & $\begin{array}{l}\text { When their children of different religion present, the } \\
\text { prayer is done in a form of a song without reference } \\
\text { to God. }\end{array}$ \\
\hline & No & 2,9 & $\begin{array}{l}\text { If there is a child that is not Christian Orthodox in the } \\
\text { class he/she simply does not participate in the prayer }\end{array}$ \\
\hline \multirow{3}{*}{$\begin{array}{l}\text { Theme } \\
4\end{array}$} & Co - operation with parents & 12,7 & \\
\hline & Yes & 8,4 & $\begin{array}{l}\text { After I explained to parents why I do everything I do, I } \\
\text { told them that I had no problem their children to do } \\
\text { their own prayer }\end{array}$ \\
\hline & No & 4,8 & $\begin{array}{l}\text { If a child or a parent requests not to participate, then } \\
\text { the child does not participate }\end{array}$ \\
\hline \multirow[t]{3}{*}{$\begin{array}{l}\text { Theme } \\
\mathbf{5}\end{array}$} & $\begin{array}{l}\text { Activities for promotion of } \\
\text { diversity in relation to religion - } \\
\text { prayer }\end{array}$ & 27,6 & \\
\hline & Yes & 20,9 & $\begin{array}{l}\text { During the year, activities are carried out in order to } \\
\text { present and explain the differences and similarities of } \\
\text { different cultural perceptions }\end{array}$ \\
\hline & No & 7,7 & We never talk about such matters in the classroom \\
\hline \multirow{3}{*}{$\begin{array}{l}\text { Theme } \\
6\end{array}$} & Imposition of prayer for parents & 5,9 & \\
\hline & Yes & 1,3 & $\begin{array}{l}\text { However, it has been observed that mothers of } \\
\text { different religion cross themselves and teach their } \\
\text { children to do so, in order for them not to differ from } \\
\text { the rest of the children }\end{array}$ \\
\hline & No & 4,8 & $\begin{array}{l}\text { Many times parents themselves force their children } \\
\text { not to participate in celebrations and prayers }\end{array}$ \\
\hline $\begin{array}{l}\text { Theme } \\
7\end{array}$ & Demand of respect & 3,4 & $\begin{array}{l}\text { The primary purpose of a prayer is to maintain respect } \\
\text { and quietness among all the children }\end{array}$ \\
\hline
\end{tabular}

Table 5.Thematic Analysis of the responses at the question (How do you cope with the Morning Prayer?)

\begin{tabular}{|c|c|c|c|c|}
\hline \multirow[t]{2}{*}{ Themes } & \multirow[t]{2}{*}{ Title } & Categories & $\%$ & Statements \\
\hline & & Total & 22,2 & \\
\hline \multirow{5}{*}{$\begin{array}{l}\text { Theme } \\
1\end{array}$} & \multirow{5}{*}{ Frequency } & Never & 9,1 & \\
\hline & & Once a day & 4,4 & \\
\hline & & Twice a day & 4,0 & \\
\hline & & $\begin{array}{l}\text { Three times a } \\
\text { day }\end{array}$ & 4 & \\
\hline & & Four times a day & 4,4 & \\
\hline \multirow{6}{*}{$\begin{array}{l}\text { Theme } \\
2\end{array}$} & \multirow{4}{*}{ Procedure } & Total & 55,6 & \\
\hline & & Relaxed & 21,8 & $\begin{array}{l}\text { Many children are from foreign countries and because of } \\
\text { this fact, we do not pray }\end{array}$ \\
\hline & & Medium & 30,2 & $\begin{array}{l}\text { Sometimes the schedule is overloaded and then the } \\
\text { prayer can be omitted }\end{array}$ \\
\hline & & Extreme & 3,6 & We don't start our daily activities if we don't pray first \\
\hline & & Total & 11,5 & \\
\hline & & Neutral & 4,4 & $\begin{array}{l}\text { I think it is good to make children pray at school, but } \\
\text { without putting pressure or marginalizing them. }\end{array}$ \\
\hline
\end{tabular}




\begin{tabular}{|c|c|c|c|}
\hline \multirow[t]{2}{*}{$\begin{array}{l}\text { Theme } \\
3\end{array}$} & Extreme Christian & 2,4 & $\begin{array}{l}\text { We live in Greece, in a Christian country and our prayer } \\
\text { in a kindergarten should have a strictly orthodox } \\
\text { Christian character }\end{array}$ \\
\hline & $\begin{array}{l}\text { Extreme religious } \\
\text { tolerance }\end{array}$ & 4,8 & $\begin{array}{l}\text { I believe that religious education is parents' } \\
\text { responsibility, not teachers'. }\end{array}$ \\
\hline \multirow[b]{4}{*}{$\begin{array}{l}\text { Theme } \\
4\end{array}$} & Total & 10,3 & \\
\hline & Not important & 2,0 & $\begin{array}{l}\text { I'm not there to teach them a prayer, but to help them } \\
\text { gain some skills }\end{array}$ \\
\hline & Important & 7,9 & $\begin{array}{l}\text { It is a preparation of children for the next year and for } \\
\text { the rest of their lives }\end{array}$ \\
\hline & Very important & 4 & $\begin{array}{l}\text { Prayer in a kindergarten is very important because it } \\
\text { offers children an opportunity to come in contact with } \\
\text { religion }\end{array}$ \\
\hline
\end{tabular}

There is a statistically significant correlation between the topics and prayer and tolerance $(p<0,05$ and $F=14,1$ and 5,9 correspondigly). Similarly, significant correlation was observed in relation to sex $(p<0,05, f=3,9)$, experience $(p<0,05, f=2,4)$, position $(p<0,05, f=5,4)$, urbanity $(p<0,05, f=2.1)$ and prayer $(p<0,05, f=3,5)$.

Relating the experience to the other topics, we observe that the majority of reports concentrated on the topic "promotion of diversity" $(20,5 \%)$ and "exemption right" (13,5\%), while the fewest reports were gathered on the topics "parents' imposition" (1,3\%) and "prayer adjustment" (2,9\%). Analyzing the results of subcategories, we observe that most reports come from kindergarten teachers with experience of eleven to twenty years, with most of them emphasizing the necessity to implement activities for promotion of diversity $(23,2 \%)$ and the right to exempt children from the process of prayer $(12,7 \%)$. The views seem to be shared in the first category, where $9,2 \%$ of reports support the imposition of prayer over the remaining 9,2\%. Fewer reports are collected from teachers with experience between six and ten years (76) and more than twenty (61), where we find prayer adjustment according to the composition of the class $(10,5 \%$ and $8,2 \%$ respectively), but also a conflict regarding the right of exemption from prayer ( $15,8 \%$ and $18 \%$ respectively), with $14,5 \%$ in favor and $16,4 \%$ against. Finally, it is noteworthy that from the reports of the newly appointed and deputy teachers, the need for promotion of diversity through activities $(44,8 \%)$ is emphasized, while there are no attempts to impose prayer (0\%).

Regarding the correlation of teacher's position with the topics, we observe that the majority of views concentrates on the "promotion of diversity" $(20,5 \%)$ and on the category "prayer exemption" $(13,6 \%)$ and "prayer adjustment" (10,1\%). More specifically, the majority of reports collected focuses on the subcategory of permanent teachers (248), where the promotion of diversity through activities and actions $(14,9 \%)$ and adjustment of prayer according to the composition of the class $(11,3 \%)$ are emphasized. The views regarding the imposition of prayer in the classroom (7,7\% compared to $10,5 \%$ against) and the right to exclude children from prayer $(9,3 \%$ compared to $11,3 \%$ against) seem to be shared. Noteworthy is the fact that $23,8 \%$ of the reports of the heads, holding a permanent position, do not give the right to the children to be excluded from prayer, while simultaneously the $23,8 \%$ of reports describe attempts to promote diversity through activities. Additionally, $9,5 \%$ of the reports document no cooperation with the parents, against $9,5 \%$ that do, while $4,8 \%$ of the reports demonstrates the "imposition of prayer" against 4,8\% that does not. On the other hand, deputy teachers seem not to provide the exemption right $(5,1 \%)$ in their attempt to faithfully follow the standard procedures and fearing the reactions of other parents. Nevertheless, they concentrate the largest number of reports supporting the implementation of activities promoting diversity $(53,8 \%)$, while at the same time the $15,4 \%$ refrain from such activities.

The correlation of urbanization with the categories demonstrates that most reports focus on the categories of "promotion of diversity" (18,8\%) and "exemption right" $(15,5 \%)$, while very few reports refer to collaboration with parents where the 5,5\% admits parent-teacher non-cooperation versus just 1,5\% which seems to cooperate. Specifically, it appears that the majority provides children with right of exemption from pray in 
urban and suburban areas (14,4\% and $23,6 \%$ respectively) while a significant percentage refers to the failure to provide it (9,6\% and $12,7 \%$ respectively). In all areas there is prayer adjustment according to the composition of the class, as an effort to promote diversity through the respective activities. The effort to cooperate with parents is mentioned more in urban areas (11,2\%), while for the category "imposition of prayer" the predominance of non-imposition in suburban areas (10,9\% vs. 5,5\%) is observed. The views seem to be divided in the urban areas, where $7,4 \%$ imposes prayer against $7,4 \%$ that does not and likewise in the rural areas degree $(7,1 \%)$, respectively.

Finally, regarding the relationship of prayer with the categories, most of the reports focus on the promotion-of-diversity activities (20,5\%), and the right of exemption (13,6\%). Regarding the type of prayer, reports of teachers who exclusively use Christian orthodox prayer impose it $(11,6 \%)$ without granting the right of exemption $(17,9 \%)$ and while they seem to promote activities promoting the diversity (17,9\%), essentially, they do not adjust the prayer according to the composition of the class (4\%) neither do they cooperate with parents $(1,7 \%)$ towards finding a solution. In contrast, the reports of teachers who do not pray in the class show the highest rate of adjustment depending on the composition of the class (50\%) and collaboration with parents $(12,5 \%)$. Noteworthy is the fact that there are no reports on the need to implement activities to promote diversity (0\%) while it is emphasized that parents are the ones who require the children to pray, in order to integrate quickly into and not stand out from the dominant group (12,5\%). In contrast, the reports of teachers who do a general prayer emphasize the need for implementing diversity promoting activities (26,5\%) and the tendency of parents to prevent children from participating in the prayer even though it is generic in order not to drift from dominant group (8,5\%). Finally, it is obvious that the teachers, who make prayers of all religions in the classroom, allow for exemption (20\%) and simultaneously adjust the prayer according to the composition of the class (10\%). Noteworthy here is the fact that there are more reports on avoidance of diversity promoting activities (30\%) than on their promotion (20\%).

\section{Discussion}

The way people perceive cultural identities depends on how they have been these identities shaped and produced (Grossberg, 1994). Nowadays new identities have been arisen, mainly constructed by racial and cultural differentiation. Along with class identity, race, religion and ethnicity became the filters and the division criteria of the modern societies. These criteria have been spread to every aspect of social life.

Until the beginning of the nineties the composition of the Greek society was culturally and religiously solid. The entrance of various immigrants in Greece differentiated the cultural origin of the population in Greek society, in Greek schools and in labour. Until recently this was a shock not only for the ordinary citizen but for the Greek government and the state as well. This shock was the main source of various social and educational policies which were stacked to the doctrine of the undifferentiated Greek population. Nowadays the Greek society and the Greek government have realized that in Greece live and people from other countries. Their culture and their religion are different than the Greek culture and the Orthodox Christianity.

It's important to point out that only a small percentage of the Greek kindergarten teachers who participate to the research believe that every student has to pray according to the demands of the Greek Orthodox ritual. On the contrary a notable percentage of the sample recognizes the diversities (cultural and religious) that exist within their classrooms and tries to handle them deferentially recognizing the religious autonomy of the children and their parents (Lester, 2004). Attitudes and beliefs like those which mentioned above could be characterized as radical and revolutionary a few years ago but the climate seems to have changed today.

Kindergarten teachers might now realize that it is of a crucial importance for children to feel that are accepted by their class mates as an undivided part of the class, and the others don't care whether they are different. This is a crucial condition for the children in order to develop their self-esteem (Lawrence, 1988). Moreover it is well known that the ethnic or the cultural identity of the children affects their whole development (Gay, 1985). This new reality arose due to the training that offered from many universities and other institutions in Greece. Long life training helped to change the attitudes of the educators and offered them opportunities to improve their skills for the management of cultural diverse classes. The findings of this research saw us that the field religion and prayer is not easy to alter. This has to do with the importance given by the educational system and a significant part of the society to the matters of religion. For the Greek educational reality it's important 
that there is a notable part of teachers who have a critical attitude towards the orthodox prayer in cultural diverse classes and try to find other solutions such as the use of a neutral approach of the prayer. The problem is that the educators don't take any action to ensure the right of the children to pray.

A crucial question arises: Is the compulsory the one and only Morning Prayer harmful for children with diverse cultural identities? Or Morning Prayer has to be at the choice of teachers or the parents? Haynes (1998: 18) declared, "Schools cannot be in the business of religious indoctrination. But at the same time, schools have an obligation to make sure religion is taken seriously» (as cited by Romanowski, 2002).

\section{References}

Anonymous, School Prayer in //en.wikipedia/wiki/School prayer .

Bandin, L. (1977). L' analyse de contenu. Paris: PUF.

Berelson, B. (1971). Content Analysis in Communication Research. New York: The Free Press.

Clogg R. (1984), Short History of Modern Greece, Athens: Kardamitsas (in Greek).

Creswell, J. (2008). Research Design: Qualitative, Quantitative, and Mixed Methods Approaches. London: Rutledge.

Crook D., Freathy R., Wright S. (2011). Citizenship, Religion and Education. History of Education,40, 695-700. DOI:10.1080/0046760X.2011.638801

Cross, W. (1985) Black Identity: Rediscovering the distinctions between personal identity and reference group orientation, pp. 155-172, in Spencer, M. et al (Eds.) Beginnings: The Social and Affective Development of Black Children. N.J.: Erlbaum Hillsdale.

Coulby, D. (2008). Intercultural education: Religion, knowledge and the limits of postmodernism. Intercultural Education, 19(4), 305-314.

DOI: $10.1080 / 14675980802376838$

Derman-Sparks L. \& A.B.C. Force (2004), Anti-Bias Curriculum. Tools for empowering young children. Washington D.C.: National Association for Young Children, Greek Edition, Schedia, Athens.

De Sola Pool, I. (1959). Content analysis. Urbana, Ill: University of Illinois Press.

Durkheim E. (1995). Elementary forms of Religious Life. New York: The Free Press.

Efstathiou I., Zisimos A. , Georgiadis F. (2008). Religion in Greek society at the time of Globalization. Intercultural Education, 19(4), 325-336. DOI: $10.1080 / 14675980802376853$

Gay, G. (1985). Implications of Selected Models of Ethnic Identity Development for Educators. Journal of Negro Education, 54(1), 43-55.

Giroux, H. and McLaren, P. (1994) (eds). Between Borders: pedagogy and the politics of cultural studies. New York: Routledge.

Grawitz, M. (1981). Methodes des sciences sociales. Paris: Dalloz.

Gundara, J. (1990) Societal Diversity and the Issue of the Other. Oxford Review of Education, 16(1), 97-109. DOI: $10.1080 / 0305498900160108$

Gundara J. (2000). Religion Human Rights and Intercultural Education.Intercultural Education, 11(2), 127-136. DOI: $10.1080 / 713665241$

Haynes,C.C., and Thomas, O. (1995). Beyond the schoolprayer debate: Taking religion seriously in publicschools.Rights, Responsibilities and Respect: A News letter from the California Three R's Project. (winter/ spring ).

Holsti, O.R. (1969). Content Analysis for the Social Sciences and the Humanities. Mass: Addison-Wesley.

Kofos E (1997). National Heritage and National Identity in $19^{\text {th }}$ and $20^{\text {th }}$ Century Macedonia" in Veremis Th. (ed.)National Identity and Nationalism in Modern Greece, 199-269, Athens: National Bank Educational Foundation (in Greek).

Krippendorff, K.(2012). Content Analysis: An Introduction to Its Methodology. London: SAGE.

Lagarde, J. D. (1983). Initiation a l'Analyse des Donees. Paris: Dunod.

Lasswell, H. D, \& De Sola Pool, I. (1952). The comparative study of symbols. Stanford: Stanford University Press.

Lasswell, H. D., \& Leites, N. (1965). The Language of Politics: Studies in Quantitative Semantics. New York: MIT Press.

Lawrence, D. (1988). Enhancing Self-esteem in the Classroom. London: Paul Chapman.

Leetaru, K. (2011). Data Mining Methods for the Content Analyst: An Introduction to the Computational Analysis of Content. London: Rutledge.

Lester, E. (2004). Religious Autonomy and World Religions Education. Religion \& Education, 31(2), 62-82. DOI:10.1080/15507394.2004.10012341 
Luciak M. (2006). Minority Schooling and Intercultural Education: a comparison of recent developments in the old and new EU member States. Intercultural Education,17(1), 73-80. DOI: 10.1080/14675980500502370

Mayes, C. \& Ferrin, S. E. (2001). Spiritually committed public school teachers: Their beliefs and practices concerning religious expression in the classroom. Religion and Education, 28(1), 75-94. DOI: 10.1080/15507394.2001.10012270

Milot, M. (2007). The religious dimension of intercultural education, in J.Keast, Religious Diversity and Intercultural Education. Brussels: Council of Europe.

Moscovici, S. (1970). La psychanalyse, son image et son public. Paris: PUF

Mucchieli, R. (1988). L'analyse de contenu des documents et des communications. Paris: Les Editions ESF.

Palmquist, M. (1990). The lexicon of the classroom: language and learning in writing classrooms. (Unpublished Doctoral Dissertation). Carnegie Mellon University.

Pantazis S. and Sakellariou M (2004),Religious education in Pre-School Age.Proceedings of International Congress "Moral and Religious Developmentand education of the child", University of Creta, Rethymno, 305-313.

Romanowski, M.H. (2002). Is School Prayer the Answer? The Educational Forum, 66(2), 154-161. DOI: 10.1080/00131720208984817.

Russo, C.J. (2003). Religion and Public Schools: A Forty Year Retrospective. Religion and Education, 31(2), 1-22.

Siraj-Blatchford, L.I. (1996). Values, Culture and Identity in Early Childhood Education. International Journal of Early Years Education, 4(2), 63-69. DOI: $10.1080 / 0966976960040206$

Sotirelis G (1998).Religion and Education:The constitution and the European Convention.From catechism to pluralis. Athens: Sakkoulas (in Greek).

Stavrianos, K., (2003). Religious Education in Pre-Scool Education.Proceedings of International Congress "Moral and Religious Developmentand education of the child", University of Creta, Rethymno.

Vairinou, K. and Kamaroudis, St., (2004) "Moral and Religious Education in Kindergarten", Proceedings of International Congress "Moral and Religious Development and education of the child", University of Creta, Rethymno, 206-219 (in Greek).

Veron, E. (1981). La construction des evenements. Paris: Les Editions de Minuit.

Verma, G. and Bagley, C. (1987). Personality, Cognition and Values. Calgary: Calgary University Press.

Vrame, An., (2009). An Overview of Orthodox Christian Religious Education, (pp 277-292) in M. de Souza et al. (eds.) International Handbook of the Religious, Moral and Spiritoual Dimensions in Education, AA Dordrecht: Spinger.

Weber, R. P. (1990). Basic Content Analysis. Newbury Park, CA: Sage.

Zambeta E (2008). Religion, modernity and social rights in European education. Intercultural Education, 19(4), $297-304$.

Zambeta E. (2000). Religion and national identity in Greek education. Intercultural Education, 11(2), 145-155.

Zoumas E.(2001). The contribution of religious education in young children's socialization. Makednon, 8, 179-190. 